\title{
Isolation of a subtilisin-like serine protease gene (MyxSubtSP) from spores of Myxobolus cerebralis, the causative agent of whirling disease
}

\author{
Christoph Dörfler, Mansour El-Matbouli*
}

Institute of Zoology, Fish Biology and Fish Diseases, University of Munich, Kaulbachstraße 37, 80539 Munich, Germany

\begin{abstract}
Proteases play important roles in parasite life cycles and host-parasite interactions. They are pathogenesis factors of many pathogenic organisms and are hence potential targets for chemotherapeutic treatment of disease. We identified a subtilisin-like serine protease gene, $\mathrm{MyX}_{\mathrm{X}}$ SubtSP, expressed by Myxobolus cerebralis. After PCR with subtilisin-like serine protease primers, the gene was cloned, sequenced and aligned against the NCBI database. Its corresponding amino acid sequence included the putative conserved domains of Peptidase_S8, subtilase family and AprE, subtilisin-like serine proteases. Rapid amplification of 5' and 3' cDNA ends (RACE) was used to generate the full length (1385 bp) gene, with a $429 \mathrm{bp}$ open reading frame. The gene encompasses coding regions for a catalytic triad formed by Asp-74, His-100 and Ser-110.
\end{abstract}

KEY WORDS: Salmonid whirling disease $\cdot$ Myxobolus cerebralis $\cdot$ Serine protease $\cdot$ Cloning

\section{INTRODUCTION}

The metazoan parasite Myxobolus cerebralis is the causative agent of salmonid whirling disease, which was originally described in rainbow trout from Germany (Hofer 1903). The parasite was subsequently widely disseminated through the international fish trade (Halliday 1976). In North America, the disease initially appeared in Pennsylvania and Nevada in 1958, followed by Connecticut (1961), Virginia (1965), California and Massachusetts (1966). Whirling disease is now in at least 22 states in the US and has been associated with catastrophic declines in populations of wild rainbow trout Oncorhynchus mykiss (Nehring \& Walker 1996, Vincent 1996, Hedrick et al. 1998, Baldwin et al. 2000).

Myxobolus cerebralis has a 2-host life cycle involving the freshwater oligochaete worm Tubifex tubifex as primary host. After ingestion, $M$. cerebralis myxospores undergo 3-phase development in the intestinal epithelium of the oligochaete: comprising schizogony, gametogony and sporogony to generate triactinomyxon actinospores which are released into the water (El-Matbouli et al. 1998). The triactinomyxons can then infect a salmonid host by entering through the epidermis (Wolf \& Markiw 1984, El-Matbouli \& Hoffmann 1989).
Whirling disease of salmonids is diagnosed from 3 primary symptoms: pathological 'whirling' behaviour (Rose et al. 2000), darkening of the caudal part of the body (Schäperclaus 1990) and deformation of the head and spinal column (Hoffman et al. 1962). Although the life cycle of Myxobolus cerebralis has been well described, the mechanisms by which the parasite invades the fish epidermis, migrates through host tissues and promotes disruption of chondrocytes remain unresolved. It is hypothesised that these processes are facilitated by proteases generated by the parasite (Kelley et al. 2004). Proteases are known to play an important role in lesion formation and virulence of many pathogenic organisms (McKerrow 1989, McKerrow et al. 1993) and are known to enable invasion of parasites into their hosts by catalysing degradation of connective tissues. Subtilisin-like genes, which code for proteolytic enzymes, are involved in the process of host invasion for Neospora caninum (Louie \& Conrad 1999, Louie et al. 2002), Toxoplasma gondii (Miller et al. 2001), and Plasmodium falciparum (Blackman et al. 1998, Hackett et al. 1999).

Within the host, proteases are involved in parasite metabolism and in evasion of host immune responses by degradation or activation of host immune mole- 
cules. They can also facilitate degradation of host cytoskeletal proteins, activation of parasite regulatory proteins, metamorphosis of the parasite, and can affect blood coagulation and the host fibrinolytic system (McKerrow et al. 1993). Proteases are important for both parasite physiology and development (Rosenthal et al. 1988, McKerrow 1989, 1999, McKerrow et al. 1993, 1999) and contribute to parasite virulence (Que \& Reed 2000, Que et al. 2002, 2003, Mackey et al. 2004); hence these enzymes are targets for potential antiparasite treatments.

The objective of this study was to identify parasite proteases that may contribute to the pathogenicity of Myxobolus cerebralis. We focused on whether M. cerebralis possesses serine proteases, and what kinds of serine proteases are present. Herein we describe the isolation of a subtilisin-like serine protease gene, MyxSubtSP, from spores of Myxobolus cerebralis.

\section{MATERIALS AND METHODS}

Zymography. Percoll ${ }^{\circledR}$ (Sigma-Aldrich Chemie)purified Myxobolus cerebralis triactinomyxon spores $\left(1.5 \times 10^{6} \mathrm{ml}^{-1}\right)$ were ultrasonicated for $10 \mathrm{~min}$, then diluted 1:1 with Laemmli sample buffer. Sodium dodecyl sulphate (SDS) gels containing $12 \%$ acrylamide were polymerised in the presence of $1 \mathrm{mg} \mathrm{ml}^{-1}$ gelatin (Muñoz et al. 2000). Wells were loaded for each inhibitor to be tested plus a negative control. After electrophoresis, the gel was cut into individual lanes, which were then incubated in $2.5 \%$ Triton $\mathrm{X}$ for $1 \mathrm{~h}$ to remove SDS and restore proteolytic activity. The gel slices were rinsed twice in phosphate-buffered saline (PBS), then incubated overnight at room temperature in PBS baths ( $\mathrm{pH} 7.4)$ containing each of the inhibitors: antipain $\left(100 \mu \mathrm{g} \mathrm{ml}^{-1}\right)$, aprotinin $(100 \mathrm{mM}), \mathrm{E}-64$ (Ltrans-epoxysuccinyl-leucylamidi-4-guanidino-butane) $(5 \mu \mathrm{M})$, leupeptin $\left(100 \mu \mathrm{g} \mathrm{ml}{ }^{-1}\right)$; pepstatin $(1 \mu \mathrm{M})$, phenantrolin (100 mM) (all Sigma-Aldrich Chemie), and a negative control containing PBS alone. Before they were added to the baths, the inhibitors were first dissolved in water, except phenanthrolin which was dissolved in dimethylsulphoxide (DMSO), and pepstatin which was dissolved in ethanol. After incubation, the gel slices were stained for $1 \mathrm{~h}$ in a $0.1 \%$ amido black solution comprising methanol $(40 \%)$, acetic acid $(10 \%)$ and water $(50 \%)$, then de-stained in an equivalent solution without the amido black. Proteolytic compounds appeared in the gel as clear bands against a blue background, i.e. where digestion of copolymerised gelatin occurred. Any inhibitory effects resulted in disappearance of bands.
Parasite preparation and nucleic acid isolation. Triactinomyxon spores of Myxobolus cerebralis were filtered from an infected culture of Tubifex tubifex oligochaetes, enumerated in $50 \mu \mathrm{l}$ filtered water and purified on a Percoll ${ }^{\circledR}$ gradient (Sigma-Aldrich Chemie). RNAlater (Sigma-Aldrich Chemie) was added to the purified spores which were then stored at $-20^{\circ} \mathrm{C}$ until used for RNA extraction. Total RNA was extracted using a RNeasy Mini Kit (Qiagen). Complementary DNA (CDNA) was generated using a Super SMART ${ }^{\mathrm{TM}}$ PCR cDNA Synthesis Kit (BD Biosciences). cDNA samples were stored at $-20^{\circ} \mathrm{C} ;$ extracted RNA was kept at $-80^{\circ} \mathrm{C}$.

Serine protease primer PCR amplification. Universal primers were used in PCR amplification of cDNA from triactinomyxon spores (Sakanari et al. 1989, Elvin et al. 1993, Blackman et al. 1998). Specific primers were then used to amplify chymotrypsin-like serine proteases (Sakanari et al. 1989): forward primer 5'ACA GAA TTC TGG GTN GTN CAN GCN GCN CAY TG-3', reverse primer 5'-ACA GAA TTC ARN GGN CCN CCN SWR TCN CC-3', and to amplify subtilisinlike serine proteases (Blackman et al. 1998): forward primer 5'-CAY GGI ACI CAY GTI GCI GG-3'; reverse primer 5'-CCI GCI ACR TGI GGI GTI GCC AT-3'. All primers were synthesised by MWG-Biotech AG).

PCR was performed in $50 \mu \mathrm{l}$ volumes, which comprised approximately $100 \mathrm{ng}$ of triactinomyxon cDNA and $47.5 \mu \mathrm{l}$ of $1.1 \times$ Reddy-Mix ${ }^{\mathrm{TM}}$ PCR master mix (ABgene): $1.25 \mathrm{U}$ Taq DNA polymerase, $75 \mathrm{mM}$ Tris$\mathrm{HCl}(\mathrm{pH} 8.8), 20 \mathrm{mM}\left(\mathrm{NH}_{4}\right)_{2} \mathrm{SO}_{4}, 1.5 \mathrm{mM} \mathrm{MgCl}$, $0.01 \%(\mathrm{v} / \mathrm{v})$ Tween $20,0.2 \mathrm{mM}$ each of dATP, dCTP, dGTP and dTTP), and $50 \mathrm{pmol}$ of each primer. Amplifications were performed in a Mastercycler gradient thermocycler (Eppendorf) using the parameters of Brown \& Reece (2003): $94^{\circ} \mathrm{C}$ for 2 min followed by 2 cycles of $94^{\circ} \mathrm{C}$ for $2 \mathrm{~min}, 25^{\circ} \mathrm{C}$ for $1 \mathrm{~min}$ and $72^{\circ} \mathrm{C}$ for $2 \mathrm{~min}$, followed by 40 cycles of $94^{\circ} \mathrm{C}$ for $2 \mathrm{~min}, 55^{\circ} \mathrm{C}$ for $2 \mathrm{~min}$ and $72^{\circ} \mathrm{C}$ for $2 \mathrm{~min}$, and a final extension at $72^{\circ} \mathrm{C}$ for $10 \mathrm{~min}$. PCR products were visualised on ethidium bromide-stained $1.5 \%$ agarose gel with $1 \mathrm{~kb}$ DNA ladder.

Cloning, sequencing and alignment. Amplicons were excised from the gel and purified using a MinElute ${ }^{\mathrm{TM}}$ Gel Extraction Kit (Qiagen). A TOPO ${ }^{\circledR}$ TA cloning kit (Invitrogen) was used according to the manufacturer's instructions to ligate $4 \mu \mathrm{l}$ of each amplicon into the TA cloning vector $\mathrm{pCR}^{\circledR} 4$ and to transform chemically competent Escherichia coli. The optical density (OD) ${ }_{600}$ of the bacteria cultures was determined using an Eppendorf biophotometer. Cultures with an $\mathrm{OD}_{600}$ between 2.0 and 4.0 were used for plasmid DNA extraction with a FastPlasmid Mini Kit (Eppendorf). Plasmid DNA was sent to Sequence Laboratories Göttingen for sequencing. Sequences were aligned using the National Center for Biotechnology (NCBI) BLAST program. 
5' and 3' rapid amplification of CDNA ends (RACE). The 5' and $3^{\prime}$ ends of the subtilisin-like serine protease gene were amplified using a 5'/3' RACE kit (Roche Molecular Biochemicals). First-strand 5' cDNA templates were produced according to the manufacturer's protocol. We used $2 \mu \mathrm{g}$ of total RNA with $12.5 \mu \mathrm{M}$ of gene-specific primer 5'RACE $\mathrm{SP}_{\mathrm{S} 1}$ : 5'-CCG CAA TCA CAC TCG ACA GTC TAC-3'. After purification and tailing reaction, PCR amplification of the cDNA was performed in $50 \mu \mathrm{l}$, comprising $5 \mu \mathrm{l}$ dA-tailed cDNA, $1 \mu \mathrm{l}$ oligo dT-anchor primer, $1 \mu \mathrm{l}$ deoxynucleotide mixture, $0.5 \mu$ l Taq DNA polymerase (Roche), $5 \mu$ reaction buffer (10× conc.), $36.5 \mu \mathrm{l} \mathrm{H}{ }_{2} \mathrm{O}, 1 \mu \mathrm{l}(12.5 \mu \mathrm{M})$ of genespecific primer $5^{\prime} \mathrm{RACE}_{\mathrm{SP} 2}$ : 5'-TTA GCC CCT GAG GCT ACT CCT ACG-3'. RACE amplification was carried out in a thermocycler using the following parameters: $94^{\circ} \mathrm{C}$ for $2 \mathrm{~min}$, followed by 35 cycles of $94^{\circ} \mathrm{C}$ for $15,60^{\circ} \mathrm{C}$ for $30 \mathrm{~s}$, and $72^{\circ} \mathrm{C}$ for $1 \mathrm{~min}$, with a final extension of $72^{\circ} \mathrm{C}$ for $7 \mathrm{~min}$.

Synthesis of first-strand 3' cDNA was carried out according to the manufacturer's protocol: $2 \mu \mathrm{g}$ of total RNA were used in a $50 \mu \mathrm{l} \mathrm{PCR}$, comprising $1 \mu \mathrm{l}$ 3' CDNA product, $1 \mu \mathrm{l}$ PCR anchor primer, $1 \mu$ l deoxynucleotide mixture, $0.5 \mu \mathrm{l}$ Taq DNA polymerase, $5 \mu \mathrm{l}$ reaction buffer (10× conc.), $40.5 \mu \mathrm{H}_{2} \mathrm{O}$, and $12.5 \mu \mathrm{M}$ gene-specific primer $3{ }^{\prime} \mathrm{RACE}_{\mathrm{SP} 5}$ : 5'-ACG CTA TGC TAT TTT GTC AGG G-3'. The PCR cycle conditions were the same as for 5' first-strand synthesis. Both 5'- and 3'-PCR samples were visualised, purified, cloned and sequenced as described above.

Phylogenetic analysis. The amino acid sequence corresponding to Nucleotides 859 to 1287 from $M y x$ SubtSP and subtilisin-like serine protease sequences from other species obtained from the NCBI database were aligned using the CLUSTAL W program (Thompson et al. 1994). Phylogenetic analysis of 100 replicates was conducted with the distance matrix method. The matrix was calculated using the Fitch-program of PHYLIP Version 3.65 (Felsenstein 2004). The tree was visualised using TreeView32 (Page 1996).

\section{RESULTS}

\section{Zymography}

Protease activity was indicated by 2 bands on the SDS-PAGE gel, molecular weights 29 and $55 \mathrm{kDa}$ (Fig. 1).

The inhibitors we tested did not give a result clear enough to allow the type of protease to be determined by zymography. For antipain, a non-selective serine and cystein protease inhibitor, both bands disappeared, indicating that antipain inhibited both proteolytic activities. For aprotinin, which inhibits serine

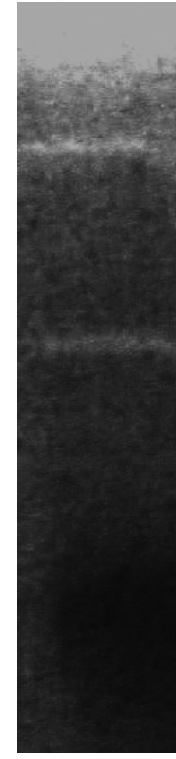

$55 \mathrm{kDa}$

Fig. 1. Myxobolus cerebralis. Protease zymogram using gelatin SDS-PAGE

proteases including trypsin, chymotrypsin, kallikrein and plasmin, the $29 \mathrm{kDa}$ band disappeared. For E-64 an effective inhibitor of cystein proteases that neither affects cystein residues in other enzymes nor reacts with low molecular weight thiols such as calpain and cathepsin B, neither band disappeared. For leupeptin, an inhibitor of serine and cystein proteases including plasmin, trypsin, papain and Cathepsin B, both bands disappeared. For pepstatin, a potent inhibitor of acid proteases, including pepsin, renin and Cathepsin D and many aspartic proteases, both bands disappeared. For phenanthrolin, a metallo protease inhibitor, only the $55 \mathrm{kDa}$ band disappeared (Table 1).

Table 1. Tested inhibitors and their effect on the 29 and $55 \mathrm{kDa}$ protease expressed by Myxobolus cerebralis. +: band still visible after treatment with relevant inhibitor; -: band disappeared

\begin{tabular}{|llcc|}
\hline Inhibitor & $\begin{array}{l}\text { Type of protease(s) } \\
\text { inhibited }\end{array}$ & $\begin{array}{c}29 \mathrm{kDa} \\
\text { band }\end{array}$ & $\begin{array}{c}55 \mathrm{kDa} \\
\text { band }\end{array}$ \\
\hline Antipain & $\begin{array}{l}\text { Serine and cystein } \\
\text { proteases }\end{array}$ & - & - \\
Aprotinin & $\begin{array}{l}\text { Serine proteases } \\
\text { E-64 }\end{array}$ & - & + \\
Leupeptin & $\begin{array}{l}\text { Cystein proteases } \\
\text { Serine and cystein }\end{array}$ & + & + \\
proteases & - & - \\
Pepstatin & $\begin{array}{l}\text { Acid and aspartic } \\
\text { proteases }\end{array}$ & - & - \\
& $\begin{array}{l}\text { Metallo proteases } \\
\text { Phenanthrolin }\end{array}$ & + & - \\
\hline
\end{tabular}




\section{PCR with serine protease primer}

No bands were detected when chymotrypsin-like serine protease primers were used. Subtilisin-like serine protease primers generated a $~ 500 \mathrm{bp}$ amplicon, which was excised from the gel, and cloned to yield a 503 bp sequence which we designated MyxSubtSP. A BLASTP search indicated putative conserved domains with Peptidase_S8, subtilase family (pfam Accession No. PF00082) and AprE, subtilisin-like serine proteases (COG Accession No. COG1404).

\section{Rapid amplification of cDNA ends (RACE)}

RACE amplification generated a 250 bp amplicon for $3^{\prime}$ and $>1 \mathrm{~kb}$ for $5^{\prime}$. Amplicons were excised from the gel, cloned and sequenced to yield 262 and $1122 \mathrm{bp}$ respectively. The full length gene consisted of $1385 \mathrm{nu}-$ cleotides with a $429 \mathrm{bp}$ open reading frame. Start codon
ATG was at Positions 859 to 861, and the termination codon TAA was at 1285 to 1287 . Amino acid sequence analysis of MyxSubtSP showed 3 catalytic sequences (Asp-74, His-100, Ser-110) (Figs. 2 \& 3). Alignment of the complete sequence using NCBI's BLASTP program confirmed the putative conserved domains.

\section{Phylogenetic analysis}

A phylogenetic tree generated with the distance matrix model of multiple subtilisin-like serine proteases, grouped MyxSubtSP from Myxobolus cerebralis with subtilisin-like serine proteases from the fungi Metharizium anisopliae var. anisopliae, Coprinopsis cinerea, Saccharomyces cerevisiae and Podospora anserina, although the bootstrap values were low (Fig. 4). This clustering was also apparent from trees generated with parsimony and maximum likelihood models (not shown).

\begin{tabular}{|c|c|c|}
\hline 1 & СTTTGCCGGATCAAGAGCTACCAACTCTTTTCCGAAGGTAACTGGCTTCAGCAGAGCGCA & \\
\hline 61 & GATACCAAATACTGTTCTTCTAGTGTAGCCGTAGTTAGGCCACCACTTCAAGAACTCTGT & \\
\hline 121 & AGCACCGCCTACATACCTCGCTCTGCTAATCCTGTTACCAGTGGCTGCTGCCAGTGGCGA & \\
\hline 181 & TAAGTCGTGTCTTACCCGGGTTTGGACTCAAGACGATAGTTACCGGATAAGGCGCAGCGG & \\
\hline 241 & TCGGGCTGAACGGGGGGTTCGTGCACACAGCCCAGCTTGGAGCGAACGACCTACACCGAA & \\
\hline 301 & CTGAGATACCTACAGCGTGAGCTATGAGAAAGCGCCACGCTTCCCGAAGGGAGAAAGGCG & \\
\hline 361 & GACAGGTATCCGGTAAGCGGCAGGGTCGGAACAGGAGAGCGCACGAGGGAGCTTCCAGGG & \\
\hline 421 & GGAAACGCCTGGTATCTTTATAGTCCTGTCGGGTTTCGCCACCTCTGACTTGAGCGTCGA & \\
\hline 481 & TTTTTGTGATGCTCGTCAGGGGGGCGGAGCCTATGGAAAAACGCCAGCAACGCGGCCTTT & \\
\hline 541 & TTACGGTTCCTGGCCTTTTGCTGGCCTTTTGCTCACATGTTCTTTCCTGCGTTATCCCCT & \\
\hline 601 & GATTCTGTGGATAACCGTATTACCGCCTTTGAGTGAGCTGATACCGCTCGCCGCAGCCGA & \\
\hline 661 & ACGACCAAGGGCGAATTCGCCCTTGACCACGCGTATCGATGTCGACTTTTTTTTTTTTTT & \\
\hline 721 & TTCTCCGTAGGAGTAGCCTCAGGGGCTAAGATTGTAGCGCTCAAAGTACTTGATCAGTTG & \\
\hline 781 & GGCGAAGGTAGACTGTCGAGTGTGATTGCGGCGGTGGCGCATGTTAGCCAAAATGCTACA & \\
\hline 841 & GCGGGAGATGTCGTCAATATGAGTTTGGGACTAGATGGTACCTCCGCTGCACTAGACAGG & \\
\hline 901 & $\begin{array}{rlllllllllllll}\text { M } & \text { S } & \text { L } & \text { G } & \text { L } & \text { D } & \text { G } & \text { T } & \text { S } & \text { A } & \text { A } & \text { L } & \text { D } & \text { R } \\
\text { GAAGTTCAAGCAGCCGCTAACAAAGGCATTCTTTTTGCAATAGCGGCCGGCAACGATGCC } \\
\end{array}$ & 14 \\
\hline & $\begin{array}{llllllllllllllllllll}\mathrm{E} & \mathrm{V} & \mathrm{Q} & \mathrm{A} & \mathrm{A} & \mathrm{A} & \mathrm{N} & \mathrm{K} & \mathrm{G} & \mathrm{I} & \mathrm{L} & \mathrm{F} & \mathrm{A} & \mathrm{I} & \mathrm{A} & \mathrm{A} & \mathrm{G} & \mathrm{N} & \mathrm{D} & \mathrm{A}\end{array}$ & 34 \\
\hline 961 & AAGCAAGCCAACGGATACTCGCCAGCAAGGGTCAATCATGCCAATATATTTACGGTGTCG & \\
\hline & $\begin{array}{llllllllllllllllllll}\mathrm{K} & \mathrm{Q} & \mathrm{A} & \mathrm{N} & \mathrm{G} & \mathrm{Y} & \mathrm{S} & \mathrm{P} & \mathrm{A} & \mathrm{R} & \mathrm{V} & \mathrm{N} & \mathrm{H} & \mathrm{A} & \mathrm{N} & \mathrm{I} & \mathrm{F} & \mathrm{T} & \mathrm{V} & \mathrm{S}\end{array}$ & 54 \\
\hline 1021 & GCGGTAGATAGCACAGGGCGATTTGCTAGTTTCTCCAATTACGGTAACGATGTAGTAGAT & \\
\hline & $\begin{array}{llllllllllllllllllll}A & V & D & S & T & G & R & F & A & S & F & S & N & Y & G & N & D & V & V & D\end{array}$ & 74 \\
\hline 1081 & GTAGCCGCCTATGGTGTCAGGGTACGTTCGACTTATTCAAACGGACGCTATGCTATTTTG & \\
\hline & $\begin{array}{llllllllllllllllllll}\mathrm{V} & \mathrm{A} & \mathrm{A} & \mathrm{Y} & \mathrm{G} & \mathrm{V} & \mathrm{R} & \mathrm{V} & \mathrm{R} & \mathrm{S} & \mathrm{T} & \mathrm{Y} & \mathrm{S} & \mathrm{N} & \mathrm{G} & \mathrm{R} & \mathrm{Y} & \mathrm{A} & \mathrm{I} & \mathrm{L}\end{array}$ & 94 \\
\hline 1141 & TCAGGGTATTTTGATCACGGACAAAAAATAGCTCTGACTGTATTTTCTTTCATTAACTCA & \\
\hline & $\begin{array}{llllllllllllllllllll}\mathrm{S} & \mathrm{G} & \mathrm{Y} & \mathrm{F} & \mathrm{D} & \mathbf{H} & \mathrm{G} & \mathrm{Q} & \mathrm{K} & \mathrm{I} & \mathrm{A} & \mathrm{L} & \mathrm{T} & \mathrm{V} & \mathrm{F} & \mathbf{S} & \mathrm{F} & \mathrm{I} & \mathrm{N} & \mathrm{S}\end{array}$ & 114 \\
\hline 1201 & АTAATTCCATCATGTGTTGCTTATAAGTACTTTAAAGTCGCATTTGAAGCTAGATTTTCC & \\
\hline & $\begin{array}{lllllllllllllllllllll}I & I & P & S & C & V & A & Y & K & Y & F & K & V & A & F & E & A & R & F & S\end{array}$ & 134 \\
\hline 1261 & AATCGATTCGATGTAGTGGTGGATTAAATTTATCTCAATGACAATTAAAACGTTTAATTA & \\
\hline & $\begin{array}{lllllllll}\mathrm{N} & \mathrm{R} & \mathrm{F} & \mathrm{D} & \mathrm{V} & \mathrm{V} & \mathrm{V} & \mathrm{D} & *\end{array}$ & 142 \\
\hline 321 & AAAAATTTCTTTTAATTTTCTAACCTCTAAAAAAAAAAAAAAAAGTCGACATCGATACGC & \\
\hline & & \\
\hline
\end{tabular}

Fig. 2. Nucleotide and deduced amino acid sequence of the cloned subtilisin-like serine protease gene MyxSubtSP. Numbers on the left denote nucleotide sequences, those on right amino acid sequences. Amino acid sequence starts with methionine (Met-1) residue, and is represented by the single-letter code below the underlined nucleotide sequence. The catalytic triad Asp-74, His-100, Ser-110 is in boldface. Stop codon is indicated by an asterix $\left(^{*}\right)$ 


\author{
Myxobolus cerebralis \\ Metarhizium anisopliae var. anisopliae \\ Saccharomyces cerevisiae \\ Bacillus subtilis \\ Chloroflexus aurantiacus
}

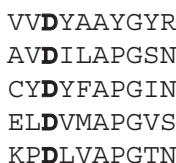

$\begin{array}{ll}\text { GYF---DHGQ } & \text { KIALTVFSFI } \\ \text { GTSMATPHIV } & \text { GLGAYLASLE } \\ \text { GTSMASPHYA } & \text { GILSYFLSLQ } \\ \text { GTSMATPHVA } & \text { GAAALILS-- } \\ \text { GTSMAGPHVA } & \text { GAVALIWSAN }\end{array}$

Fig. 3. Catalytic triad (boldface) of $M y x$ SubtSP and regions flanking active site for comparison. Amino acid sequences surrounding catalytic active site of MyxSubtSP (Asp-74, His-100, Ser-110) from Myxobolus cerebralis were aligned to the following subtilisin-like serine proteases: subtilisin-like protease PR1I (Metarhizium anisopliae var. anisopliae, CAC95043), subtilisin-like protease III (Saccharomyces cerevisiae, AAA35237), subtilisin (Bacillus subtilis, CAE18180) and subtilisin-like serine protease (Chloroflexus aurantiacus, ZP00357443)

\section{DISCUSSION}

Proteases play an integral role in interactions between parasites and their hosts, and underlie the pathogenicity of many organisms (McKerrow 1989, McKerrow et al. 1993). These enzymes have also been described in Myxobolus cerebralis (Kelley et al. 2003, 2004) and are possibly a key pathogenesis factor of this parasite, which causes salmonid whirling disease. Introduced to the USA in the 1950s, whirling disease spread rapidly and devastated both wild trout and hatchery populations. Recently, rainbow trout resistant to the disease (Strain H) was discovered in Germany (Hedrick et al. 2003). The mechanisms which underlie the greater resistance of the $\mathrm{H}$ strain are currently unknown. We hypothesise that differences in the way this German strain and a susceptible strain from North America (Strain TL) respond to parasite proteases contributes to their different susceptibility to the disease.

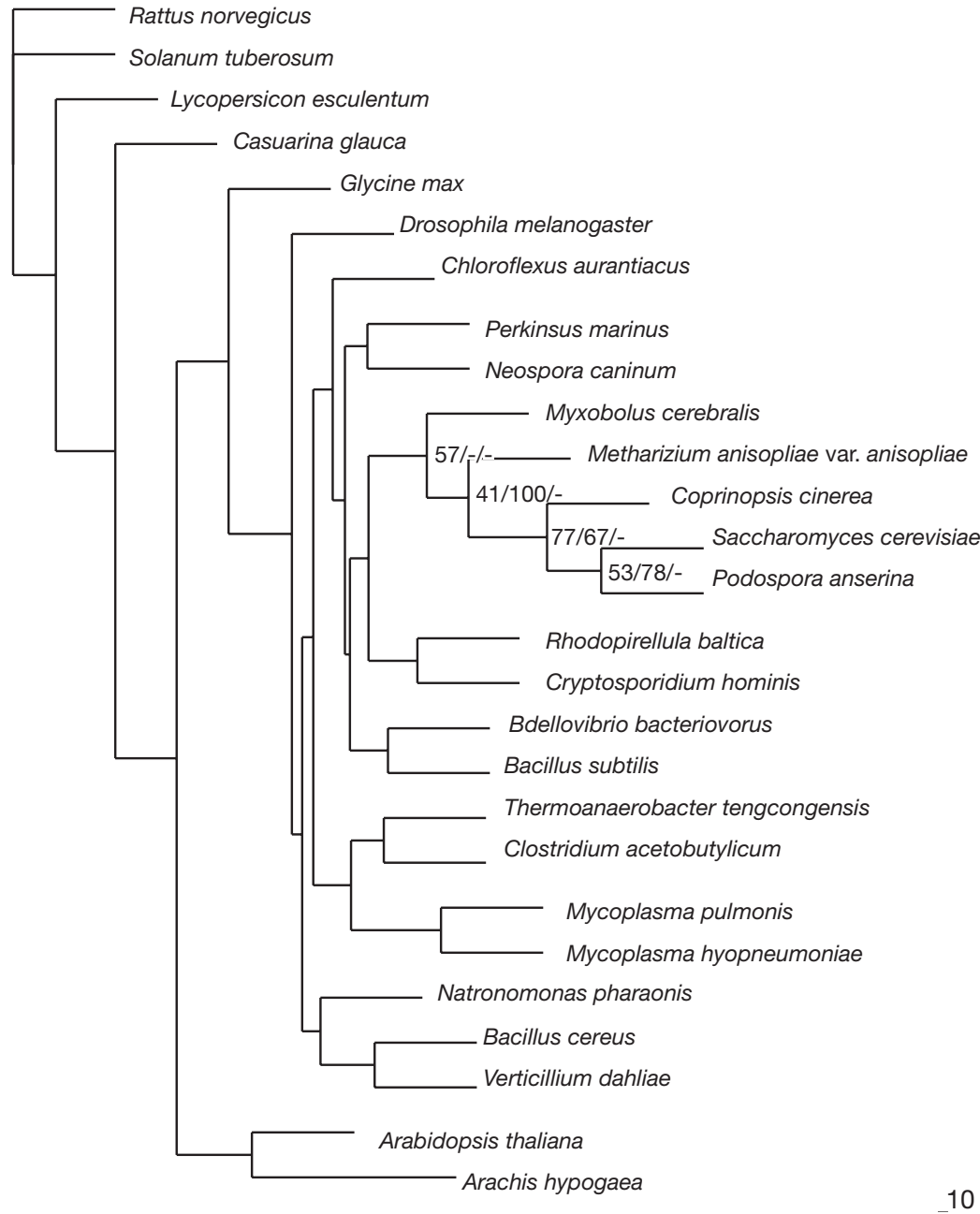

Fig. 4. Phylogenetic distance matrix tree generated following CLUSTAL W (Thompson et al. 1994) alignment of the MyxSubtSP sequence determined from Myxobolus cerebralis and following subtilisin-like serine protease sequences: AAA61987, Rattus norvegicus, AAF04257, Neospora caninum; AAQ54746, Perkinsus marinus; CAE18180, Bacillus subtilis; CAE80099, Bdellovibrio bacteriovorus; BAC78619, Coprinopsis cinerea; AAC03564, Podospora anserina; CAC95043, Metharizium anisopliae var. anisopliae; AAA35237, Saccharomyces cerevisiae; ZP_00357443, Chloroflexus aurantiacus, AAY63882: Solanum tuberosum, CAA07001, Lycopersicon esculentum; AAO62352, Casuarina glauca; AAD02075, Glycine max; BAB70678, Arabidopsis thaliana; AAY54007, Arachis hypogaea; AAM24081, Thermoanaerobacter tengcongensis; AAU15651, Bacillus cereus; CAI50405, Natronomonas pharaonis; AAS45251, Verticillium dahliae; NP_350134, Clostridium acetobutylicum; YP_287727, Mycoplasma hyopneumoniae; CAD71780, Rhodopirellula baltica; AAC28563, Drosophila melanogaster; CAC13828, Мусоplasma pulmonis; XP_667589, Cryptosporidium hominis. Numbers at nodes indicate bootstrap values for distance matrix, parsimony and maximum likelihood. Values below 50 are not shown 
In the present study, zymography suggested the presence of serine proteases in Myxobolus cerebralis, which corresponds to the studies of Kelley et al. (2004), who were the first to identify and characterise a serine protease gene from $M$. cerebralis. Of the 6 inhibitors tested, 3 serine protease inhibitors, antipain, aprotinin, and leupeptin, affected parasite protease activity. To amplify the putative protease gene, we used generic primers for chymotrypsin-like and subtilisin-like serine proteases, given the widespread occurrence of both enzyme types in nature (Barret et al. 1998). Although $M$. cerebralis has a protease with a catalytic residue arrangement similar to that of the chymotrypsin family of serine proteases (Kelley et al. 2004), we could not detect a band with the degenerate chymotrypsin-like serine protease primers that we used. With the subtilisin-like serine protease primers we obtained an amplicon designated MyxSubtSP.

Serine proteases are the largest family of proteolytic enzymes (McKerrow et al. 1993) and are grouped into 6 clans (SA, SB, SC, SE, SF, SG) with 27 families, denoted S1 to S27 (Rawlings \& Barrett 1994). Subtilases belong to the superfamily of subtilisin-like serine proteases. Over 200 subtilases are presently known and complete amino acid sequences for more than 170 have been elucidated (Siezen \& Leunissen 1997). Alignment of MyxSubtSP to the database of known protease sequences revealed a putative conserved domain with Peptidase_S8, subtilase family.

The common catalytic apparatus of serine proteases consists of a nucleophilic serine residue adjacent to histidine, with aspartate in an unconserved position to complete a catalytic triad (Perona \& Craik 1995). In MyxSubtSP, we determined that the 3 sequences Asp74, His-100 and Ser-110 comprised the catalytic triad. The linear arrangement of these catalytic residues places MyxSubtSP in the subtilisin clan (SB) (Rawlings \& Barrett 1993, 1994).

In the phylogenetic analysis, the subtilisin-like serine protease from rat was the clear outgroup. High similarities were found between MyxSubtSP and the subtilisin-like serine proteases of fungi Coprinopsis cinerea, Podospora anserina, Metharizium anisopliae var. anisopliae and Saccharomyces cerevisiae. Although these clustered in the phylogenetic tree, bootstrap values were quite low, which was most likely due to the use of short sequences with significantly variable regions.

The isolation of MyxSubtSP allows for analysis of the subtilisin-like serine protease in the infection process in susceptible and non-susceptible trout, for instance by means of quantitative transcription studies during experimental infection of the $\mathrm{H}$ and the TL strains.
Acknowledgements. This work was supported by the Whirling Disease Foundation and the US Fish and Wildlife Service. We also thank Dr. H. Soliman and Dr. E. Eszterbauer for their assistance with the molecular phylogenetic work

\section{LITERATURE CITED}

Baldwin TJ, Vincent ER, Silflow RM, Stanek D (2000) Myxobolus cerebralis infection in rainbow trout (Oncorhynchus mykiss) and brown trout (Salmo trutta) exposed under natural stream conditions. J Vet Diagn Investig 12: 312-321

Barret AJ, Rawlings ND, Wuessner JF (1998) Handbook of proteolytic enzymes. Academic Press, London, p 284-366

Blackman MJ, Fujioka H, Stafford WHL, Sajid M and 5 others (1998) A subtilisin-like protein in secretory organelles of Plasmodium falciparum merozoites. J Biolog Chemi 273: 23398-23409

Brown GD, Reece KS (2003) Isolation and characterization of serine protease gene(s) from Perkinsus marinus. Dis Aquat Org 57:117-126

El-Matbouli M, Hoffmann RW (1989) Experimental transmission of two Myxobolus spp. Developing bisporogeny via tubificid worms. Parasitol Res 75(6):461-464

El-Matbouli M, Holstein TW, Hoffmann RW (1998) Determination of nuclear DNA concentration in cells of Myxobolus cerebralis and triactinomyxon spores, the causative agent of whirling disease. Parasitol Res 84:694-699

Elvin CM, Whan V, Riddles PW (1993) A family of serine protease genes expressed in adult buffalo fly (Haematobia irritans exigua). Mol Genet Genomics 240:132-139

Felsenstein J (2004) PHYLIP (phylogeny inference package) Version 3.6 (distributed by the author). Department of Genome Sciences, University of Washington, Seattle, WA

Hackett F, Sajid M, Withers-Martinez C, Grainger M, Blackman M (1999) PfSUB-2: a second subtilisin-like protein in Plasmodium falciparum merozoites. Mol Biochem Parasitol 1036:183-195

Halliday MM (1976) The biology of Myxosoma cerebralis: the causative organism of whirling disease in salmonids. J Fish Biol 9:339-357

Hedrick RP, El-Matbouli M, Adkison MA, MacConnell E (1998) Whirling disease: re-emergence among wild trout. Immunol Rev 166:365-376

Hedrick RP, McDowell TS, Marty GD, Fosgate GT, Mukkatira K, Myklebust K, El-Matbouli M (2003) Susceptibility of two strains of rainbow trout (one with suspected resistance to whirling disease) to Myxobolus cerebralis infection. Dis Aquat Org 55:37-44

Hofer B (1903) Über die Drehkrankheit der Regenbogenforelle. Allg Fisch-Ztg 28:7-8

Hoffman GL, Dunbar CE, Bradford A (1962) Whirling disease of trout caused by Myxobolus cerebralis in the United States. US Fish Wildl Serv Spec Sci Rep Fish 427:1-14

Kelley GO, Adkinson MA, Leutenegger CM, Hedrick RP (2003) Myxobolus cerebralis: identification of a cathepsin Z-like protease gene (MyxCP-1) expressed during parasite development in rainbow trout, Oncorhynchus mykiss. Exp Parasitol 105:201-210

Kelley GO, Zagmutt-Vergara FJ, Leutenegger CM, Adkison MA, Baxa DV, Hedrick RP (2004) Identification of a serine protease gene expressed by Myxobolus cerebralis during development in rainbow trout Oncorhynchus mykiss. Dis Aquat Org 59:235-248 
Louie K, Conrad PA (1999) Characterization of a cDNA encoding subtilisin-like serine protease (NC-p65) of Neospora caninum. Mol Biochem Parasitol 103: 211-223

Louie K, Nordhausen R, Robinson TW, Barr BC, Conrad PA (2002) Characterization of Neospora caninum protease, NcSUB1 (NC-p65), with rabbit anti-N54. J Parasitol 88: $1113-1119$

Mackey ZB, O'Brien TC, Greenbaum DC, Blank R, McKerrow $\mathrm{JH}$ (2004) A Cathepsin B-like protease is required for host protein degradation in Trypanosoma brucei. J Biol Chem 279:48426-48433

McKerrow JH (1989) Parasite proteases. Exp Parasitol 68: 111-115

McKerrow JH (1999) Development of cysteine protease inhibitors as chemotherapy for parasitic diseases: insight on safety, target validation, and mechanism of action. Int $\mathrm{J}$ Parasitol 29:833-837

McKerrow JH, Sun E, Rosenthal PJ, Bouvier J (1993) The proteases and pathogenicity of parasitic protozoa. Annu Rev Microbiol 47:821-53

McKerrow JH, Engel JC, Caffrey CR (1999) Cysteine protease inhibitors as chemotherapy for parasitic infections. Bioorg Med Chem 7:639-644

Miller SA, Binder EM, Blackman MJ, Carruthers VB, Kim K (2001) A conserved subtilisin-like protein TgSUB1 in microneme organelles of Toxoplasma gondii. J Biol Chem 276:45341-45348

Muñoz P, Sitjà-Bobadilla A, Àlvarez-Pellitero P (2000) Antigenic characterization of Sphaerospora dicentrarchi (Myxosporea: Bivalvulida), a parasite from European sea bass Dicentrarchus labrax (Teleostei: Serranidae). Dis Aquat Org 40:117-124

Nehring RB, Walker PG (1996) Whirling disease in the wild: the new reality in the intermountain west. Fisheries 21: 28-32

Page RDM (1996) TREEVIEW: an application to display phylogenetic trees on personal computers. Comput Appl Biosci 12:357-358

Perona JJ, Craik CS (1995) Structural basis of substrate specifity in the serine proteases. Protein Sci 4:337-360

Editorial responsibility: Dieter Steinhagen,

Hannover, Germany
Que X, Reed SL (2000) Cysteine proteinases and the pathogenesis of amebiasis. Clin Microbiol Rev 13(2):196-206

Que X, Ngo H, Lawton J, Gray M and 6 others (2002) The Cathepsin B of Toxoplasma gondii, Toxopain-1, is critical for parasite invasion and rhoptry protein processing. J Biol Chem 277:25791-25797

Que X, Kim SH, Sajid M, Eckmann L, Dinarello CA, McKerrow JH, Reed SL (2003) A surface amebic cysteine proteinase inactivates interleukin-18. Infect Immun 71:1274-1280

Rawlings ND, Barrett AJ (1993) Evolutionary families of peptidases. Biochem J 290:205-218

Rawlings ND, Barrett AJ (1994) Families of serine peptidases. Methods Enzymol Suppl Methods 244:19-61

Rose JD, Marrs GS, Lewis C, Schisler G (2000) Whirling disease behaviour and its relation to pathology of brain stem and spinal cord in rainbow trout. J Aquat Anim Health 12:107-118

Rosenthal PJ, McKerrow JH, Aikawa M, Nagasawa H, Leech JH (1988) A malarial cysteine proteinase is necessary for haemoglobin degradation by Plasmodium falciparum. J Clin Investig 82:1560-1566

Sakanari J, Staunton E, Eakin A, Craik C, McKerrow JH (1989) Serine proteases from nematode and protozoan parasites: isolation of sequence homologs using generic molecular probes. Proc Natl Sci Acad USA 86:4863-486

Schäperclaus W (1990) Fischkrankheiten, 5. Auflage. Akademie-Verlag, Berlin

Siezen RJ, Leunissen JA (1997) Subtilases: the superfamily of subtilisin-like serine proteases. Protein Sci 6:501-523.

Thompson JD, Higgins DG, Gibson TJ (1994) Improving the sensitivity of progressive multiple sequence management, analysis, and homology determination. Nucleic Acids Res 22:4673-4680

Vincent ER (1996) Whirling disease and wild trout: the Montana experience. Fisheries 21:32-34

Wolf K, Markiw ME (1984) Biology contravenes taxonomy in the Myxozoa: new discoveries show alternation of invertebrate and vertebrate hosts. Science 225:1449-1452

Submitted: June 26, 2006; Accepted: September 20, 2006 Proofs received from author(s): December 21, 2006 